\title{
Correction: Nanostructured Biomaterials for Tissue Engineered Bone Tissue Reconstruction. Int. J. Mol. Sci. 2012, 13, 737-757
}

\section{Chiara Gardin $^{1}$, Letizia Ferroni ${ }^{1}$, Lorenzo Favero ${ }^{2}$, Edoardo Stellini ${ }^{2}$, Dario Stomaci ${ }^{2}$,} Stefano Sivolella ${ }^{2}$, Eriberto Bressan ${ }^{2}$ and Barbara Zavan ${ }^{1}, *$

1 Department of Histology, Microbiology and Medical Biotechnology, University of Padova, Via G. Colombo 3, 35100 Padova, Italy; E-Mails: chiara.gardin@unipd.it (C.G.); letizia.ferroni@unipd.it (L.F.)

2 Department of Periodontology, School of Dentistry, University of Padova, Via Venezia 90, 35100 Padova, Italy; E-Mails: lorenzo.favero@unipd.it (L.F.); edoardo.stellini@unipd.it (E.S.); dstomaci@yahoo.it (D.S.); stefano.sivolella@libero.it (S.S.); eriberto.bressan@unipd.it (E.B.)

* Author to whom correspondence should be addressed; E-Mail: barbara.zavan@unipd.it; Tel.: +39-049-827-6096.

Received: 4 May 2012; in revised form: 7 May 2012 / Accepted: 8 May 2012 /

Published: 24 May 2012

We would like to change the authors' names and E-Mail addresses on Page 737 of Article [1] from: Gardin Chiara $^{1}$, Ferroni Letizia ${ }^{1}$, Favero Lorenzo ${ }^{2}$, Stellini Edoardo ${ }^{2}$, Stomaci Diego ${ }^{2}$, Sivolella Stefano ${ }^{2}$, Bressan Eriberto ${ }^{2}$ and Zavan Barbara ${ }^{1} *$

1 Department of Histology, Microbiology and Medical Biotechnology, University of Padova, Via G. Colombo 3, 35100 Padova, Italy; E-Mails: Gardinc@unipd.it (G.C.); Ferronil@unipd.it (F.L.) Department of Periodontology, School of Dentistry, University of Padova; Via Venezia 90, 35100 Padova, Italy; E-Mails: Stomacid@unipd.it (S.D.); eribertobresan@unipd.it (B.E.)

To the correct version, as follows:

Chiara Gardin ${ }^{1}$, Letizia Ferroni ${ }^{1}$, Lorenzo Favero ${ }^{2}$, Edoardo Stellini ${ }^{2}$, Dario Stomaci ${ }^{2}$, Stefano Sivolella ${ }^{2}$, Eriberto Bressan ${ }^{2}$ and Barbara Zavan ${ }^{1}, *$

1 Department of Histology, Microbiology and Medical Biotechnology, University of Padova, Via G. Colombo 3, 35100 Padova, Italy; E-Mails: chiara.gardin@unipd.it (C.G.); letizia.ferroni@unipd.it (L.F.) 
2 Department of Periodontology, School of Dentistry, University of Padova, Via Venezia 90, 35100 Padova, Italy; E-Mails: lorenzo.favero@unipd.it (L.F.); edoardo.stellini@unipd.it (E.S.); dstomaci@yahoo.it (D.S.); stefano.sivolella@libero.it (S.S.); eriberto.bressan@unipd.it (E.B.)

We apologize for any inconvenience brought to the readers.

\section{References}

1. Chiara, G.; Letizia, F.; Lorenzo, F.; Edoardo, S.; Diego, S.; Stefano, S.; Eriberto, B.; Barbara, Z. Nanostructured Biomaterials for Tissue Engineered Bone Tissue Reconstruction. Int. J. Mol. Sci. 2012, 13, 737-757.

(C) 2012 by the authors; licensee MDPI, Basel, Switzerland. This article is an open access article distributed under the terms and conditions of the Creative Commons Attribution license (http://creativecommons.org/licenses/by/3.0/). 